\title{
Fc-Binding Ligands of Immunoglobulin G: An Overview of High Affinity Proteins and Peptides
}

\author{
Weonu Choe ${ }^{1,2,+}$, Trishaladevi A. Durgannavar ${ }^{2,+}$ and Sang J. Chung ${ }^{2, *}$ \\ 1 Department of Chemistry, Seoul National University, Seoul 151-742, Korea; chweha@gmail.com \\ 2 Research Institute of Biomolecular Chemistry, Dongguk University, Seoul 100-715, Korea; \\ trishalad@gmail.com \\ * Correspondence: sjchung@dongguk.edu; Tel.: +82-2-2260-8907; Fax: +82-2-2290-1523 \\ + These authors contributed equally to this work.
}

Academic Editors: Yuping Bao and Jie Zheng

Received: 15 October 2016; Accepted: 29 November 2016; Published: 8 December 2016

\begin{abstract}
The rapidly increasing application of antibodies has inspired the development of several novel methods to isolate and target antibodies using smart biomaterials that mimic the binding of Fc-receptors to antibodies. The Fc-binding domain of antibodies is the primary binding site for e.g., effector proteins and secondary antibodies, whereas antigens bind to the Fab region. Protein A, G, and $\mathrm{L}$, surface proteins expressed by pathogenic bacteria, are well known to bind immunoglobulin and have been widely exploited in antibody purification strategies. Several difficulties are encountered when bacterial proteins are used in antibody research and application. One of the major obstacles hampering the use of bacterial proteins is sample contamination with trace amounts of these proteins, which can invoke an immune response in the host. Many research groups actively develop synthetic ligands that are able to selectively and strongly bind to antibodies. Among the reported ligands, peptides that bind to the Fc-domain of antibodies are attractive tools in antibody research. Besides their use as high affinity ligands in antibody purification chromatography, Fc-binding peptides are applied e.g., to localize antibodies on nanomaterials and to increase the half-life of proteins in serum. In this review, recent developments of Fc-binding peptides are presented and their binding characteristics and diverse applications are discussed.
\end{abstract}

Keywords: Fc-binding peptide; antibody; targeted drug delivery; affinity column chromatography; Protein A; Protein A mimics; Protein G; Protein L

\section{Introduction}

Recent decades have seen the development of a myriad of applications of antibodies (Abs) and related proteins, and have become one of rapid growing classes of protein pharmaceuticals [1-6]. Abs are members of the immunoglobulin (Ig) super family and amount up to $20 \%$ of the plasma proteins. As part of the humoral immune response, Bursa lymphocytes (B-cells) are activated to differentiate into plasma cells that produce antibodies to combat pathogens and foreign substances in the host. All Abs share a common structure where two identical heavy chains glycoproteins and two identical poly peptide light chains are joined by disulfide bonds to form a large Y-shaped protein. These macromolecular proteins of $\geq 150 \mathrm{kDa}$ have two fragment antigen binding (Fab) domains where their cognate antigens bind with high selectivity and specificity. In addition, Igs display two fragment crystallizable $(\mathrm{Fc})$ regions that are the primary recognition site for e.g., cell surface receptors of effector cells, immune proteins, and other antibodies. Among the five different classes of antibodies, IgGs are the most abundant $\mathrm{Ab}$ and are also the second longest circulating protein (up to 21 days, except for IgG3 which is $\sim 7$ days) in the blood stream (albumin being the longest). The long half-life of IgG is attributed to the neonatal Fc-receptor ( $F c R n$ )-mediated endosomal salvation thereof (IgG3 lacks a crucial histidine 
residue, His435, involved in FcRn binding) [7-9]. In pharmaceutical applications of antibodies, IgG (and its subclasses) is the most prevalent Ab used. For instance, IgGs are applied as integral parts of therapeutics against a wide range of diseases (e.g., inflammation, cancer, autoimmune, and infectious diseases) and are also crucial in a variety of immunoassays such as ELISA and Western blot analysis. The wide-spread use of IgGs has necessitated the development of methods to manufacture, isolate and detect specific antibodies from complex sample mixtures [10]. In general, the production of Abs involves their expression in recombinant mammalian cell cultures followed by diverse purification steps, e.g., centrifugation, filtration, and chromatography [11].

Traditional, Ig-binding proteins, generally produced by gram-positive bacteria, have been widely explored in Ab isolation procedures [12-14]. In particular, Protein A (SpA), a virulence factor produced by Staphylococcus aureus, has been used in the chromatographic purification of Abs due to its high affinity towards IgGs from different species [15]. When the purity requirements of the final $\mathrm{Ab}$ is very strict, the utilization of these bacterial proteins in $\mathrm{Ab}$ purification is limited [16]. Besides the high production cost, one of the major problems encountered when using bacterial proteins in affinity purification of Abs is the contamination of the purified $\mathrm{Ab}$ samples with traces of these proteins (better known as ligand leakage). The contaminants may invoke an undesirable immune response when the $\mathrm{Ab}$ is used in the human body. To expand the pool of Ab binding ligands and to overcome the drawbacks associated with the use of bacterial proteins, recent decades have witnessed a great effort in the development of new $\mathrm{Ab}$ binding ligands $[17,18]$. Based on the application of the $\mathrm{Ab}$ affinity ligands, the orientation of the bound $\mathrm{Ab}$ is one of the major factors that should be considered. For instance, if the affinity ligand is used to bind Abs for usage in therapeutics and immunoassays, it is crucial that the Fab region of the $\mathrm{Ab}$ is not disturbed in order to enable binding to its cognate antigen. On the other hand, when the affinity ligand is intended for use in $\mathrm{Ab}$ purification, the binding site to the $\mathrm{Ab}$ is not of great importance as is the binding affinity.

Novel small molecules have been developed to mimic the binding properties of bacterial proteins to Abs and are extensively reviewed in literature [17-19]. Short peptides are known to selectively and strongly bind to a great variety of biomolecules. Especially cyclic peptides, as opposed to linear peptides, are reported to possess enhanced specificity and avidity towards their targets, in addition to superior enzymatic stability and conformation rigidity [20]. The straightforward synthesis, both synthetic and recombinant, allows for the generation of vast peptide libraries, and in combination with high throughput screening offers a powerful strategy to obtain high affinity binders for any given target. In particular, phage display is a robust technique that facilitates the identification of potent and selective peptide ligands to target $\mathrm{Ab}$ [21,22]. Our group actively develops applications of Fc-binding peptides and in this review we aim to give a brief overview of the traditional (bacterial protein) Fc-binding ligands and describe the development of short Fc-IgG binding synthetic peptides. Secondly, modern applications of small IgG binding ligands that target the Fc-domain of Igs will be described.

\section{Immunoglobulin Binding Proteins}

A variety of bacterial proteins are known to bind mammalian Igs, including Protein A, G, L, Z, and recombinant (fusion proteins) derivatives thereof (Figure 1, Table 1) [23-29]. SpA is known to specifically bind to the Fc-domain of Igs and is utilized in, e.g., in immunoprecipitation techniques, double sandwich immunoassays, and in affinity purification of Abs. The strong binding of SpA to various mammalian $\mathrm{Abs}\left(K_{\mathrm{d}} \sim 10 \mathrm{nM}\right.$ to IgG1) is attributed to its five homologues binding domains (A-E) that targets the $\mathrm{Fc}$-domain (between the $\mathrm{C}_{\mathrm{H}} 2$ and $\mathrm{C}_{\mathrm{H}} 3$ region) [12,30]. In addition, SpA also binds to the human Fab-heavy chain of the $\mathrm{V}_{\mathrm{H}} 3$ family [31]. The binding affinity of SpA varies for the different IgG subclasses, whereas IgG1, IgG2, and IgG4 show strong SpA binding, relative weak binding of SpA to IgG3 is observed [8]. 


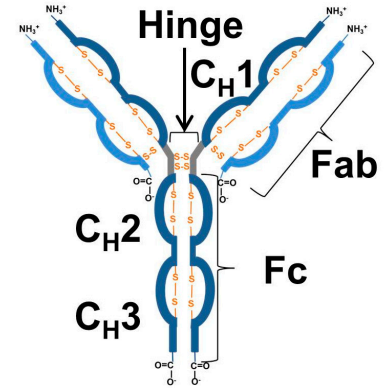

(a)

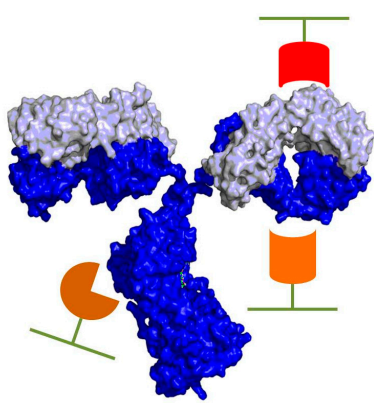

(b)

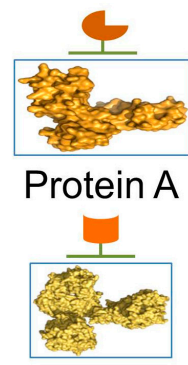

Protein $\mathrm{A}^{1}$

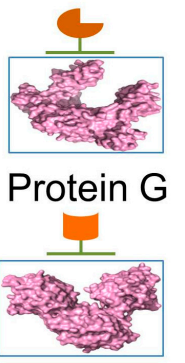

Protein $\mathrm{G}^{1}$

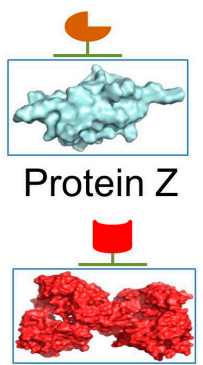

Protein L

Figure 1. Illustration of an antibody and the most common bacterial proteins used. (a) Schematic representation of the different parts of an antibody; (b) pymol-generated crystal structure of $\operatorname{IgG}$ (pdb id: 1IGT), Protein A (pdb id: 1FC2), Protein G (pdb id: 1FCC), Protein Z (pdb id: 1Q2N), Protein $A^{1}$ (pdb id: 1DEE), Protein $G^{1}$ (pdb id: 1QKZ), and Protein L (pdb id: 1HEZ).

Table 1. General properties of the most used bacterial (fusion) proteins.

\begin{tabular}{cccccc}
\hline Protein & $\boldsymbol{K}_{\mathrm{a}}{ }^{*}$ & Size & Target & Elution $\mathbf{p H}$ & References \\
\hline Protein A & $1.4 \times 10^{8} \mathrm{M}^{-1}$ & $42 \mathrm{kDa}$ & Fc, Fab & 3.5 & {$[12,29]$} \\
Protein G & $6.7 \times 10^{9} \mathrm{M}^{-1}$ & $30 \mathrm{kDa}$ & Fc, Fab, ScFv, Dab & 3.2 & {$[28]$} \\
Protein L & $5.69 \times 10^{7} \mathrm{M}^{-1}$ & 76 to $106 \mathrm{kDa}$ & Fab, ScFv, Dab, and k-light chain & 2 & {$[23]$} \\
Protein Z & $5.0 \times 10^{8} \mathrm{M}^{-1}$ & $6.7 \mathrm{kDa}$ & Fc & 3.6 & {$[24]$} \\
Protein LG & $5.9 \times 10^{9} \mathrm{M}^{-1}$ & $50 \mathrm{kDa}$ & Fc, k-light chain & 2 & {$[25]$} \\
Protein LA & $2.93 \times 10^{8} \mathrm{M}^{-1}$ & $60 \mathrm{kDa}$ & Fc, k-light chain & 2 & {$[26]$} \\
Protein AG & n.a. & $47.3 \mathrm{kDa}$ & Fc & 3 & {$[27]$} \\
\hline
\end{tabular}

* The depicted $K_{\mathrm{a}}$ values are towards IgG and may not be directly compared to each other because they were obtained at different conditions or by different methods. n.a.: Not available.

Whereas SpA in general is preferred for rabbit, pig, dog and cats, Protein G (from Streptococcal origin) possess a better binding capacity for a broader range of mouse and human IgG subclasses $\left(K_{\mathrm{a}} 6.7 \times 10^{9} \mathrm{M}^{-1}\right.$ towards human IgG) [32]. However, Protein $\mathrm{G}$ also has an albumin binding site which is one of the major constituents of serum proteins. Therefore, for Ab purification a recombinant Protein G that lacks the albumin binding site is preferred. Another bacterial Ig-binding protein is Protein L from Peptostreptococcus magnus. Protein L does not bind to the Fc-domain, but rather to the $\mathrm{k}$-light chain of $\operatorname{IgG}\left(K_{\mathrm{a}} 5.7 \times 10^{7} \mathrm{M}^{-1}\right)$ and can be used to isolate Ab fragments that do not contain the Fc-domain [23]. The great importance of Ig-binding proteins has stimulated research directed to improve their application as high affinity ligands (e.g., by mutations and synthetic derivatizations of the Ig-binding domain) [33]. In this vein, Protein Z, a synthetic protein modeled on the B-domain of SpA was reported [26,34]. In another approach, Braisted et al. designed a two-helix derivative of the Z-domain of SpA. Through the use of structure-based design and phage display optimization, a 33-mer peptide (Z33) was developed that binds to IgG1 with a $K_{d}$ of $43 \mathrm{nM}$ [35].

To improve the binding characteristics of the bacterial proteins, several fusion proteins were developed. In general, these fusion proteins combine the Ig-binding domains of the three main bacterial Proteins A, G, and L. Some interesting properties of these (fusion) proteins are listed in Table 1. In addition to fusion proteins, artificial affinity proteins of Ig are attractive alternatives to bacterial (fusion) proteins. However, the development of artificial Fc-binding proteins is beyond the scope of this review and for further information on this subject, the reader is referred to a recent review [36].

One of the drawbacks of Fc-binding bacterial proteins for use in affinity column chromatographic purification strategies of $\mathrm{Ab}$ is the relatively acidic elution condition. Under these harsh elution conditions, some $\mathrm{Ab}$ may aggregate or denature. Therefore, engineering of the $\mathrm{pH}$ sensitivity of bacterial Fc-binding protein has received much attention. One general applied strategy involves the systematical introduction of histidine residues to induce electrostatic repulsion between the affinity 
protein and the $\mathrm{Ab}$ under relative mild acidic conditions. The optimization of the $\mathrm{pH}$ response affinity using histidine-mediated electrostatic repulsion between Protein G and the Fc-domain of IgG was described by Watanabe et al. [37]. Tsukamoto et al. reported the engineering of SpA variants by a histidine-scanning library that allowed elution of $\mathrm{Abs}$ at a higher $\mathrm{pH}(\Delta \mathrm{pH} \geq 2)$ and bound IgG was eluted for $90 \%$ at $\mathrm{pH}=5$ [38]. Using site directed mutagenesis, Gulich et al. described the preparation of "destabilized" Protein $\mathrm{Z}$ mutants which allowed the elution of bound Abs at $\mathrm{pH}=4.5$, albeit that the affinity to IgG was slightly lower with respect to Protein Z [39]. Strauch et al. reported the computer design of a $\mathrm{pH}$-sensitive IgG binding protein which has a $K_{\mathrm{d}}$ of $\sim 4 \mathrm{nM}$ at slightly basic $\mathrm{pH}$ (8.2) [40]. In contrast, at acidic $\mathrm{pH}$ (5.5) the binding to IgG is about 500-fold weaker. Two different strategies, i.e., histidine scanning and random mutagenesis, were employed to gain a mutant that has a higher binding affinity at $\mathrm{pH}=7.4$ than at $\mathrm{pH}=4.5$. Gera et al. described a $\mathrm{pH}$ sensitive Fc-IgG binding protein derived from the hyperthermophilic Sso7d scaffold [41,42].

In general, the orientation of Abs can drastically influence antigen binding hence site-directed immobilization may be crucial. Bacterial proteins that bind to Abs with high affinity in a site specific manner can be used for the grafting of $\mathrm{Ab}$ on e.g., solid surfaces or to covalently attach cytotoxic compounds [43]. To generate a covalent linkage between the $\mathrm{Ab}$ and the affinity ligand, typically incubation with a bifunctional reagent (a cross-linker) is used, e.g., dimethyl pimelimidate. Jung et al. reported the modification of Protein G with a benzophenone moiety (photo cross-linker) [44]. In a similar approach, the $\mathrm{Z}$ domain of SpA was constructed using a benzophenone derived artificial amino acid and was applied in the covalent labeling of Igs [26].

\section{Immunoglobulin Binding Peptides and Peptidomimetics}

Currently, a vast number of short (cyclic) peptides are reported that can specifically bind to $\mathrm{Ab}$ and a representable selection of these peptides are depicted in Table 2 and the structures of branched and cyclic peptides are shown in Figure 2.

Table 2. A representable selection of high affinity (cyclic) peptides that selectively target immunoglobulin G.

\begin{tabular}{|c|c|c|c|c|c|}
\hline Peptide & Binding Constant & $\begin{array}{l}\text { Binding } \\
\text { Capacity * }\end{array}$ & Elution $\mathrm{pH}$ & Remarks & $\begin{array}{c}\text { Year } \\
\text { (References) }\end{array}$ \\
\hline PAM & $K_{\mathrm{d}}=0.3 \mu \mathrm{M}$ & n.a. & 3 or 9 & \multirow{3}{*}{$\begin{array}{l}\text { Dendrimer comb. library } \\
\text { SpA mimic }\end{array}$} & $1996[45]$ \\
\hline D-PAM & n.a. & 50 & 3.5 & & 2002 [46] \\
\hline D-PAM- $\Phi$ & n.a. & 10 & 4 & & $2011[47]$ \\
\hline TWKTSRISIF & n.a. & n.a. & n.a. & \multirow{2}{*}{$\begin{array}{c}\text { Phage display library } \\
\text { SpA mimic }\end{array}$} & \multirow{2}{*}{$1998[48]$} \\
\hline FGRLVSSIRY & n.a. & n.a. & n.a. & & \\
\hline Fc-III (DeLano et al.) & $K_{\mathrm{d}}=16 \mathrm{nM}$ & \multirow[b]{2}{*}{$26.6 \mathrm{mg} / \mu \mathrm{mol}$} & \multirow[b]{2}{*}{35} & \multirow{2}{*}{$\begin{array}{c}\text { Phage display cyclic peptide } \\
\text { library SpA mimic }\end{array}$} & $2000[42]$ \\
\hline Fc-III-(Sepharose) & & & & & \multirow{3}{*}{$\begin{array}{l}2016[49] \\
2006[50] \\
2016[51]\end{array}$} \\
\hline FcBP-2 & $K_{\mathrm{d}}=1.8 \mathrm{nM}$ & n.a & n.a. & Bicyclic peptide & \\
\hline Fc-III-4C & $K_{\mathrm{d}}=2.5 \mathrm{nM}$ & n.a. & 3.5 & Bicyclic peptide & \\
\hline EPIHRSTLTALL & n.a. & $320 \mu \mathrm{g} / \mathrm{g}$ & n.a. & $\begin{array}{c}\text { Phage display library } \\
\text { SpA mimic }\end{array}$ & $2001[52]$ \\
\hline APAR & $K_{\mathrm{d}}=94 \mathrm{nM}$ & 9.1 & n.a. & Comb. tetrapeptide library & 2003 [53] \\
\hline FcRM & $K_{\mathrm{d}}=20 \mu \mathrm{M}$ & n.a. & 2.7 & $\begin{array}{l}\text { Synthetic cyclic peptide } \\
\text { library, } F_{c} \gamma \text {-receptor mimic }\end{array}$ & $2005[54]$ \\
\hline HWRGWV & $K_{\mathrm{d}}=10 \mu \mathrm{M}$ & 28.4 & 4 & \multirow{4}{*}{$\begin{array}{c}\text { Comb. library } \\
\text { (one-bead-one-peptide) } \\
\text { SpA mimic }\end{array}$} & \multirow{4}{*}{$\begin{array}{l}2006[55] \\
2009[56] \\
2016[57]\end{array}$} \\
\hline HYFKFD & $K_{\mathrm{d}}=11 \mu \mathrm{M}$ & 27.0 & n.a. & & \\
\hline HFRRHL & $K_{\mathrm{d}}=26 \mu \mathrm{M}$ & 33.6 & n.a. & & \\
\hline HWCitGWV & $K_{\mathrm{d}}=108 \mu \mathrm{M}$ & 72 & n.a. & & \\
\hline \multirow{2}{*}{$\begin{array}{c}\text { D }_{2} \text { AAG } \\
\text { DAAG }\end{array}$} & $K_{\mathrm{a}}=7.9 \times 10^{5} \mathrm{M}^{-1}$ & 36.2 & 3.6 & \multirow{2}{*}{$\begin{array}{l}\text { Comb. library } \\
\text { SpA mimic }\end{array}$} & \multirow{2}{*}{$2012[58]$} \\
\hline & $K_{\mathrm{a}}=2.6 \times 10^{6} \mathrm{M}^{-1}$ & 49.6 & 3.6 & & \\
\hline \multirow{2}{*}{$\begin{array}{l}\text { cyclo[(N } \alpha-A c) S(A)- \\
\text { RWHYFK-Lact-E] } \\
\text { cyclo[(N } \alpha-A c)-D a p(A)- \\
\text { RWHYFK-Lact-E] }\end{array}$} & n.a. & n.a. & 3.5 & \multirow[t]{2}{*}{ Cyclic peptide } & \multirow[t]{2}{*}{2013 [59] } \\
\hline & n.a. & n.a. & 3.5 & & \\
\hline cyclo[Link-M-WFRHYK] & $K_{\mathrm{d}}=7.6 \mu \mathrm{M}$ & 19.7 & 4.0 & $\begin{array}{l}\text { mRNA display library } \\
\text { SpA mimic }\end{array}$ & 2013 [60] \\
\hline
\end{tabular}


Table 2. Cont.

\begin{tabular}{cccccc}
\hline Peptide & Binding Constant & $\begin{array}{c}\text { Binding } \\
\text { Capacity }\end{array}$ & Elution pH & Remarks & $\begin{array}{c}\text { Year } \\
\text { (References) }\end{array}$ \\
\hline NKFRGKYK & $K_{\mathrm{a}}=8.6 \times 10^{6} \mathrm{M}^{-1}$ & DBC-4.9 & 4.0 & Spot peptide array & $2013[61]$ \\
NARKFYKG & $K_{\mathrm{a}}=6.5 \times 10^{6} \mathrm{M}^{-1}$ & DBC-5.0 & 4.0 & Fc $\gamma$ mimic & \\
\hline FYWHCLDE(1) & $K_{\mathrm{d}}=1.5 \mu \mathrm{M}$ & 104.2 & 6.0 & Biomimetic design strategy & $2014[62]$ \\
FYCHWALE(2) & $K_{\mathrm{d}}=6.1 \mu \mathrm{M}$ & 87.6 & 6.0 & Fc-binder (SpA mimic) & $2014[63]$ \\
FYCHTIDE(3) & $K_{\mathrm{d}}=5.7 \mu \mathrm{M}$ & 63.7 & 6.0 & & $2014[64]$ \\
Dual 1/3 (2:1) & $K_{\mathrm{d}}=0.69 \mu \mathrm{M}$ & 137.9 & 6.0 & Dual affinity ligand & $2014[65]$ \\
\hline RRGW & $K_{\mathrm{d}}=0.5 \mathrm{nM}$ & n.a. & n.a. & Computer design strategy & $2014[66]$ \\
\hline \multirow{2}{*}{ KHRFNKD } & $K_{\mathrm{d}}=20 \mathrm{nM}$ & n.a. & n.a. & Phage-display library & $2015[67]$ \\
\hline
\end{tabular}

* Maximal binding capacity $\left(\mathrm{q}_{\mathrm{m}}\right)$ in $\mathrm{mg} / \mathrm{mL}$. DBC: Dynamic binding capacity. The depicted values are towards IgG and may not be directly compared to each other because they were obtained at different conditions or by different methods. n.a.: Not available.

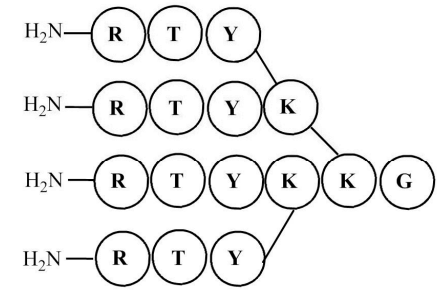

PAM; $K_{\mathrm{d}} 0.3 \mu \mathrm{M}$

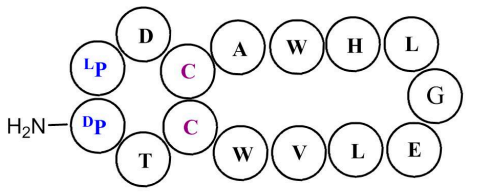

FcBP-2; $K_{\mathrm{d}} 1.8 \mathrm{nM}$

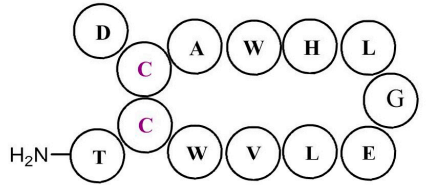

Fc-III; $K_{\mathrm{d}} 16 \mathrm{nM}$

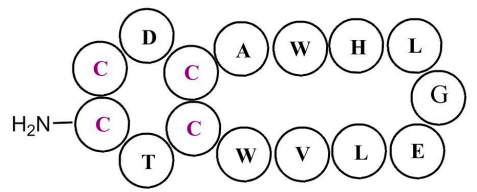

Fc-III-4C; $K_{\mathrm{d}} 2.45 \mathrm{nM}$

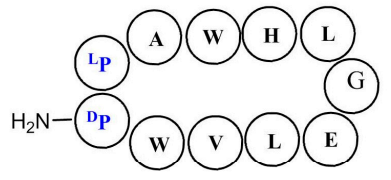

FcBP-1; $K_{\mathrm{i}} 14 \mu \mathrm{M}$

Figure 2. Structures of branched- and cyclic peptide-based high affinity ligands that bind to IgGs through interaction with the Fc-domain. The reported affinity constants are towards IgG. Elution $\mathrm{pH}$ of antibody from affinity ligand column: PAM, 3 or 9; FC-III, 3.5; Fc-III-4C, 3.5; FCRM, 2.7 [42,45,50,51,54].

In an approach to discover SpA mimetic affinity ligands, Fassina et al. (1996) screened a combinatorial peptide library composed from randomized tetramers [45]. After three rounds of selection, a dendrimeric peptide ligand with the formula (Arg-Thr-Tyr) $_{4}-\mathrm{Lys}_{2}$-Lys-Gly, denoted as PAM (Figure 2) was identified as the most active ligand to inhibit binding of SpA to biotinylated IgG. Their findings indicated that PAM binds to the Fc-region of IgG with a $K_{\mathrm{d}}$ of about $0.3 \mu \mathrm{M}$ and could target a broader range of IgG (from different species) compared to SpA. The apparent affinity constant between PAM and rabbit IgG was reported to be $3 \times 10^{5} \mathrm{M}^{-1}$. The PAM ligand was immobilized on column material and used in a one-step Ab purification from crude sera. The binding selectivity of immobilized PAM was found to be similar to SpA, and was found to be stable to column sanitizing conditions such as ethanol and $0.1 \mathrm{M}$ sodium hydroxide. In addition, the prepared affinity column was used for up to 40 consecutive $\mathrm{Ab}$ purification runs without noticeable decrease of the column capacity. A later report from the same group dealt with the preparation of the all D-amino acids version of this ligand, called D-PAM, to suppress proteolysis thereof [46].

Using Emphaze ${ }^{\mathrm{TM}}$ as the solid support to immobilize D-PAM, Ab purification was reported with a recovery yield in the range of $60 \%$ to $90 \%$ and with a purity $>90 \%$. Furthermore, prolonged incubation with mouse serum showed excellent resistance to proteolytic degradation of the D-PAM column. Further structural refinement of D-PAM, i.e., the acetylation of the four $\mathrm{N}$-terminal arginines with 
phenylacetic acid, gave D-PAM- $\Phi$ having improved binding characteristics [47]. The binding capacity of the solid-support immobilized D-PAM- $\Phi$ ligand was about one order of magnitude higher about $10 \mathrm{mg} / \mathrm{mL}$ with respect to D-PAM, giving IgG with a purity $>90 \%$. Elution of the bound Abs from the D-PAM- $\Phi$ column was achieved using $0.1 \mathrm{M}$ acetate buffer $(\mathrm{pH}=4)$.

From a phage display decapeptide library $\left(\sim 4 \times 10^{8}\right.$ different peptides), Krook et al. reported the identification of TWKTSRISIF which has a high affinity for the Fc-domain of human IgG [48]. Phage display involves the fusion of randomized amino acid sequences to filamentous phage envelope proteins by genetic engineering of the phage genome. Phage display library allows the simultaneous screening of a gigantic number of peptides to identify high affinity ligands towards a specific target. In the reported approach, a preselection of the library was preformed using streptavidin-coated paramagnetic beads to eliminate phage clones that interact with streptavidin or with the plastic. Next, the reduced library was subjected to five rounds of selection against biotinylated IgG. After the incubation time, streptavidin-coated paramagnetic beads were used to isolate the $\mathrm{Ab}$ and the bound peptides were displaced using either SpA or low $\mathrm{pH}$ (2.2).

Around two decades ago (2000), DeLano and coworkers reported the identification of a small cyclic peptide that almost exclusively bind to the Fc-region of IgG [42]. In their study, the consensus binding site on the Fc-region of IgG was probed using a bacteriophage display peptide library of $4 \times 10^{9}$ different peptides containing an intermolecular disulfide bond [22]. After several rounds of in vitro selections, a 13-mer Fc binding peptide (Fc-III, DCAWHLGELVWCT-NH ${ }_{2}$, Figure 3a) with an unusual high binding affinity towards the Fc-region of IgG was identified. Competitive assays of Fc-III with SpA showed that the binding of SpA to the Fc-domain was inhibited with a $K_{\mathrm{i}}$ of $25 \mathrm{nM}$. Albeit that Fc-III is much smaller in size with respect to SpA and Protein $\mathrm{G}\left(K_{\mathrm{d}}\right.$ about $\left.10 \mathrm{nM}\right)$, its binding to the Fc-region is only about a twofold weaker. To investigate the region and nature of the binding of Fc-III to the Fc-binding domain, the X-ray crystal structure of the Fc-III/IgG-Fc complex was determined at $2.7 \AA$ (Figure $3 b, c)$. The binding site on the Fc-domain of IgG is reported to be adaptive, exposed, nonpolar, and energetically important and primed for the interaction with multiple different molecules. Fc-III was found to be constrained in a $\beta$-hairpin conformation which is unrelated to known Fc-binding motifs, and despite having no structural similarities to natural Fc-binding proteins, Fc-III binds to the common binding site on the Fc-domain of IgG (the hinge region of the IgG-Fc domain). The importance of the internal disulfide bond was demonstrated by Dias et al. who found that reduction thereof in Fc-III completely diminished the inhibition of SpA towards Fc-binding (Table 3) [50].

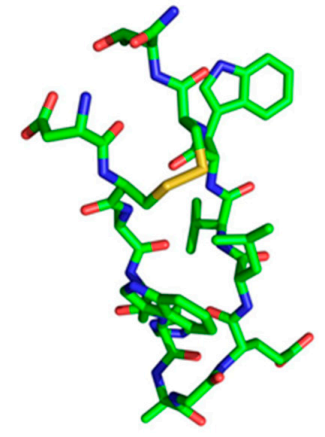

(a)

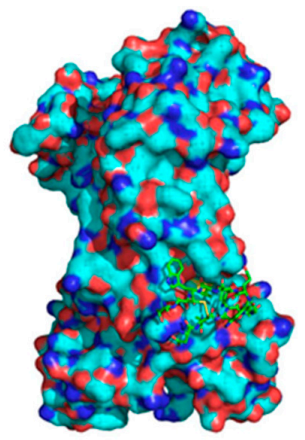

(b)

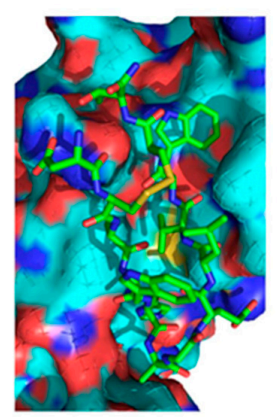

(c)

Figure 3. Structure of Fc-III binding to the Fc-region of IgG. (a) Fc-III (DCAWHLGELVWCT-NH 2 ); (b) Full view; (c) close view. Pymol generated image from a PDB file (1DN2).

The potential of Fc-III was demonstrated with the development of a re-useable (up to 60 runs) affinity purification column that gives high purity $\mathrm{Ab}(95 \%)$ [49]. Immobilization of Fc-III on sepharose had no significant effect on the binding affinity of Fc-III towards IgG and allowed elution of the bound $\mathrm{Ab}$ at $\mathrm{pH}$ comparable to Protein $\mathrm{G}$ affinity columns $(\mathrm{pH}=3.2)$. Interestingly, it was found that the 
reduced Fc-III was able to bind to IgG and allow elution at less acidic $\mathrm{pH}$ (4.8). This is in contrast to the finding of Dias et al. who reported that reduction of the disulfide bond in Fc-III results in total loss of SpA inhibition towards IgG binding [50]. One hypothesis is that reduced Fc-III binds to a different region on $\mathrm{IgG}$ or it may that the disulfide bond is reformed upon exposure to air.

Interestingly, Dias and coworkers reported in 2006 a drastic improvement of the original Fc-III peptide towards Fc binding using a small backbone cyclic peptidomimetic [50]. In the construction of the so called protein epitope mimetic, a D-Pro-L-Pro template was used to induce and stabilize the $\beta$-hairpin conformation that is present in Fc-III [68]. Computer mimetic design modeled on Fc-III and the D-Pro-L-Pro template afforded two mimetics, FcBP-1 and FcBP-2 (Figure 4). NMR spectroscopic conformational analysis (ROEs and ROESY) of FCBP-1, which lacks the crucial disulfide bridge, revealed a well-defined backbone conformation and the presence of a tight turn, however, the characteristics of the computer predicted $\beta$-hairpin was not observed. In contrast, FcBP-2, that comprises the D-Pro-L-Pro template in addition to the critical disulfide bridge, showed NOE correlations that are consistent with the expected $\beta$-hairpin backbone. Whereas FcBP-1 did not show significant inhibition of SpA binding to human IgG1, FcBP-2 was found to have an 80-fold higher affinity for the Fc-domain of human IgG1 with respect to Fc-III $\left(K_{\mathrm{i}}\right.$ of $\left.0.4 \mathrm{nM}\right)$.

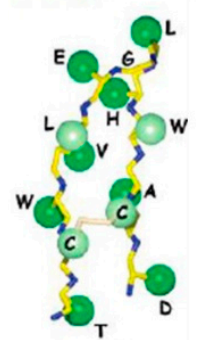

Fc-III

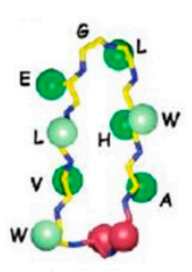

FcBP-1

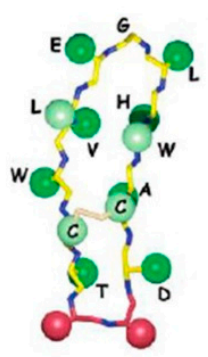

FcBP-2

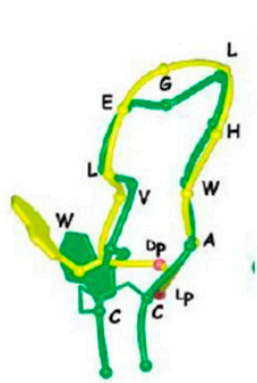

Fc-III/FcBP-1

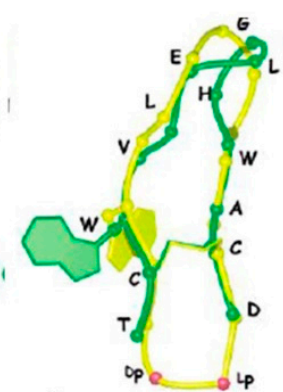

Fc-III/FcBP-2

Figure 4. Superimposition of the backbone atoms of the bound structure of Fc-III (green). Adapted from [50], with permission from (C) 2006 ACS publications.

Table 3. Affinities of various ligands that target the Fc-domain of IgG. $\mathrm{IC}_{50}$ values are from competition BIAcore assays using Protein A with standard deviations from at least three independent experiments. $K_{\mathrm{i}}$ values were determined by the method described by DeLano et al. [42]. Adapted from [50], with permission from (c) 2006 ACS publications.

\begin{tabular}{ccc}
\hline Ligand & IC $_{\mathbf{5 0}}(\mathbf{n M})$ & $\boldsymbol{K}_{\mathbf{i}}(\mathbf{n M})$ \\
\hline Fc-III, pH $=7.4$ & $460 \pm 74$ & 215 \\
Fc-III, pH $=6.0$ & $280 \pm 41$ & 41 \\
Fc-III, reduced & $>10^{6}$ & n.d. \\
FcBP-1, pH $=7.4$ & $64,800 \pm 4400$ & 14,200 \\
FcBP-1, pH $=6.0$ & $395,000 \pm 7100$ & 71,000 \\
FcBP-2, pH $=7.4$ & $32 \pm 2$ & 0.4 \\
FcBP-2, pH $=6.0$ & $35 \pm 2$ & 2.0 \\
FcBP-2, reduced, pH $=7.4$ & $550 \pm 50$ & n.d. \\
\hline
\end{tabular}

n.d.: Not determined.

Gong et al. reported a bicyclic derivative of Fc-III, based on the findings of Dias et al. (described above) detailing the enhanced binding affinity of the double cyclic FcBP-2 [51]. It was proposed that the incorporation of the D-Pro-L-Pro in addition to the $\mathrm{N}$ to $\mathrm{C}$ termini cyclization to construct FcBP-2 would present various difficulties in the recombinant production thereof. Therefore, two additional cysteine residues were added instead of the D-Pro-L-Pro template to the N- and C-termini of Fc-III, respectively, resulting in the formation of two internal disulfide bridges. The bicyclic derivative, 
FC-III-4C, showed a 30-fold increased binding affinity towards human IgG, over Fc-III and similar to FcBP-2. Furthermore, Fc-III-4C was found to bind various IgGs from different species with $K_{d}$ values in the low nanomolar range.

Interestingly, Camperi et al. reported in 2003 the affinity purification of $\mathrm{Ab}$ using a small tetrapeptide, APAR, that was identified from a combinatorial synthetic library [53]. Immobilized APAR on agarose showed a maximum $\mathrm{Ab}$ binding capacity of $9.1 \mathrm{mg} / \mathrm{mL}$ and gave electrophoretically pure anti-Granulocyte macrophage-colony stimulating factor monoclonal $\mathrm{Ab}$ (produced in mouse) in a yield of $95 \%$. Verdoliva et al. described the disulfide bridged synthetic peptide $\left(\mathrm{NH}_{2}-\mathrm{Cys}-\mathrm{Phe}-\mathrm{His}-\mathrm{His}\right)_{2}-$ Lys-Gly-OH, denoted as FcRM, as a ligand for IgG [54]. The dissociation constant of FcRM was reported to be $20 \mu \mathrm{M}$ and FcRM proved useful as an affinity ligand in the purification of IgG. Surprisingly, FcRM was shown to bind $\mathrm{Ab}$ fragments containing both Fab- and Fc-domains from different Ab isotypes which indicate that FcRM targets at least two different binding sites on the Ab.

About 10 years ago, Yang and coworkers reported a linear hexa-peptide that is able to bind to the Fc-region of IgG $[55,56]$. The screening of a synthetic library of hexa-peptides composed of $\mathrm{N}$-terminal histidine followed by aromatic amino acids performed. After a three-step screening process, three candidates were identified and among them the hexamer HWRGWV was found to be suitable for chromatographic purification of human IgG from cell culture medium. The purity of the $\mathrm{Ab}$ obtained with this ligand was comparable to commercially available resins, and slightly milder elution conditions $(\mathrm{pH}=4)$ could be used with respect to the use of $\mathrm{SpA}(\mathrm{pH}=3.5)$. The hexameric peptide was found to bind to all the subclasses of human IgGs, and furthermore, displays non-specific interactions towards human IgM and to a lesser extend to human IgA. HWRGWV binds to the Fc-region of Igs, however, it does not compete with SpA or Protein G [69]. The hexamer immobilized on Toyopearl AF Amino 650M resins has an $\mathrm{Ab}$ binding capacity of $28 \mathrm{mg} / \mathrm{mL}$ and was used to isolate human $\mathrm{IgG}$ in a yield as well as purity of $95 \%$ and the affinity column could be used up to 35 purification cycles. In 2013, the same group reported the preparation of an mRNA-display library of cyclic pentapeptides and evaluated their Fc-binding properties [60]. Solid-phase cyclisation of the mRNA-fusion peptides was achieved in good yield (87\%) and purity (94\%). The most promising candidate from the display library, cyclo[Link-M-WFRHY-K] was synthesized directly on the chromatographic Toyopearl resin and used for the isolation of human IgG. The dissociation constant of cyclo[Link-M-WFRHY-K]-Toyopearl was found to be $7.6 \mu \mathrm{M}$ and have a total $\mathrm{Ab}$ binding capacity of $20 \mathrm{mg} / \mathrm{mL}$. The purification of monoclonal IgG from industrial CHO cell culture supernatants was reported with a yield of $\sim 96 \%$ and a purity of $\sim 93 \%$. Recently, the modification of the above described hexamers with unnatural amino acids was reported to gain resistance to proteases [57].

Sugita and coworkers have reported two high affinity octameric peptides towards the Fc-region of $\operatorname{IgG}$ [61]. In their report, peptides derived from the outer membrane amino acid sequence of the IgG Fc $\gamma$ receptor, one of the well-known IgG Fc-binding proteins, were screened. Utilizing a spot-synthesized peptide array, the octameric peptides NKFRGKYK and NARKFYKG were found to have high binding affinity for the Fc-region of IgG (both mouse and human), with association constants of $8.9 \times 10^{6}$ and $6.4 \times 10^{6} \mathrm{M}^{-1}$, respectively. Both peptides were used in affinity chromatographic purification of Abs in yields of $69 \%$ (NKFRGKYK) and $80 \%$ (NARKFYKG) with purities of $83 \%$ and $68 \%$, respectively. The recovery of the $\mathrm{Ab}$ form the resin is $\mathrm{pH}$ dependent, elution at $\mathrm{pH}=6$ give low recovery yield whereas the highest recovery yield was reported when elution is performed at $\mathrm{pH}=4$.

Interestingly, Tsai and coworkers reported in 2014 a strategy to identify small peptide ligands that bind to the Fc-region of human prostate specific Ab derived from mouse IgG2a [66]. In their approach, molecular docking studies using naphthalene and end-capped tryptophan were used followed by molecular dynamics simulations to find the most suitable ligand. After additional optimizations, the tetrameric peptide RRGW was found to have a high binding affinity towards the bottom of the Fc-region of $\mathrm{Ab}$ with a $K_{\mathrm{d}}$ of $5.6 \times 10^{-10} \mathrm{M}$. SPR analysis was used to determine the recognition efficiency and orientation factor of antibodies towards RRGW bound surface. SPR studies indicated high binding affinity $\left(K_{\mathrm{a}}=1.8 \times 10^{9} \mathrm{M}^{-1}\right)$ of RRGW and mouse IgG2a. Using secondary $\mathrm{Ab}$, the 
orientation factor of IgG2a adsorption on to surface bound RRGW was examined and was found to be much higher compared to other negatively and positively charged surfaces.

For the binding of $\mathrm{Ab}$ on the surface of a quartz crystal microbalance biosensors, Yoo et al. reported the identification of a heptameric peptide KHRFNKD (ABP1) with a high and specific affinity to rabbit IgG [67]. A phage-displayed heptameric peptide library was screened for peptides that specifically bind to the Fc-domain of rabbit IgG. After four rounds of biopanning, the most active peptides were synthesized and analyzed and ABP1 was found to have a $K_{\mathrm{d}}$ of $2 \times 10^{-8} \mathrm{M}$ towards rabbit IgG, however weak binding to bovine, goat, human, and murine IgG was observed. The ABP1 fabricated biosensor was used to capture Abs without the loss of activity.

Following a biomimetic design strategy based on SpA, Zhao et al. described in 2014 the identification of the octapeptide FYWHCLDE with a dissociation constant of $1.5 \mu \mathrm{M}$ [62]. In their strategy, based on the SpA affinity motif, a 2173 member peptide library was build and evaluated using semi-flexible docking (Autodock Vina and RMSD) software. After the initial library was reduced to about 150 candidates, further computer aided modeling further reduced the library to 14 peptides. The most promising octameric peptide (FYWHCLDE) together with a negative peptide (FYTHCAKE) were selected for experimental verification. Immobilization of FYWHCLDE on Sepharose gel (with optimized ligand density of $31 \mu \mathrm{mol} / \mathrm{mL}$ ) gave a maximal Ab binding capacity of $176 \mathrm{mg} / \mathrm{mL}$ with a binding affinity $K_{\mathrm{d}}$ of $2.4-3.7 \mu \mathrm{M}$ [63]. The affinity column was reused up to 20 times showing a slight decrease $(8 \%)$ of the original binding capacity. In the same year, two more octameric Fc-binding peptides (i.e., FYCHWALE, FYCHTIDE) were reported by Zhao et al., albeit that FYWHCLDE remained the most active peptide [64]. Interestingly, an antibody affinity column was described which employs FYWHCLDE and FYCHTIDE in a molar ratio of 2:1 [65]. The dual affinity ligand column showed synergistically enhanced binding affinity towards human IgG $\left(K_{\mathrm{d}}=0.7 \mu \mathrm{M}\right)$ and gave $95 \%$ pure $\mathrm{Ab}$ with a recovery yield of $90 \%$.

\section{Modern Applications of Immunoglobulin Binding Ligands}

Ongoing research in the development of $\mathrm{Ab}$ affinity ligands has resulted in the development of several novel applications. Fc-III was used by our group to immobilize Abs on the surface of several sensors with proper orientation [70]. In this approach, Fc-III was attached to the surface of gold chips, glass slides, and magnetic beads via a polar PEG linker (Figure 5). Next, the binding of various mammalian IgGs on the Fc-III decorated surfaces was analyzed using SPR. As expected, the antigen binding ability of the Abs that are captured using Fc-III was found to be superior compared to those with random orientation.

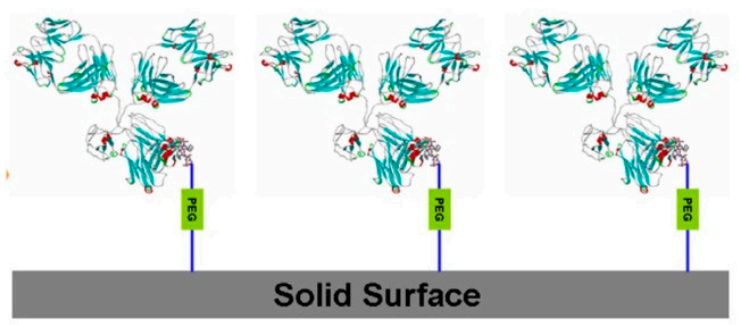

(a)

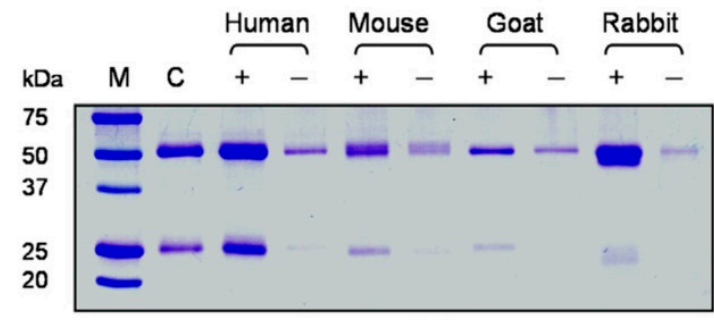

(b)

Figure 5. (a) Illustration of antibody binding on a solid surface using Fc-binding peptide Fc-III; (b) SDS-PAGE analysis of IgGs bound to Fc-III covered magnetic beads. Human IgG1 $\left(K_{\mathrm{d}}=85 \pm 5 \mathrm{nM}\right)$, mouse IgG3 $\left(K_{\mathrm{d}}>20 \mu \mathrm{M}\right)$, goat IgG3 ( $K_{\mathrm{d}}$ not given), and rabbit IgG $\left(K_{\mathrm{d}}=305 \pm 37 \mathrm{nM}\right)$ were incubated with Fc-III functionalized (+) or unmodified (-) magnetic beads. After washing steps with PBS, the bound IgG were applied to a 10\% SDS-polyacrylamide gel. Protein size marker $(\mathrm{M})$ and $1 \mu \mathrm{g}$ of human $\operatorname{IgG}(\mathrm{C})$ are indicated. Adapted from [70], with permission from @ 2016 Elsevier. 
In addition we developed an Fc-III functionalized protein nanocage (bound to anti-Her2 Ab called trastuzumab or Herceptin) to specifically target breast cancer cells (Figure 6) [71,72]. Breast cancer cells are known to overexpress Her2 receptors on the cell surface. Protein nanocages readily self-assemble from (identical) subunits to form a stable protein nanocage. In this approach, ferritin (Ft), a 24-mer protein nanocage with a diameter of $13.2 \mathrm{~nm}$ was mutated to display the Fc-binding peptide Fc-III. To this end, the Ft monomer was genetically engineered to display Fc-III in one of the loops. After the monomers self-assembled to form the protein nanocage, Fc-III was clustered on the protein surface due to the highly symmetric nature, resulting in an enhanced avidity. Next trastuzumab was fluorescently labelled with Cy3 and localized on the protein surface through binding with Fc-III, followed by fluorescent labeling of the construct.
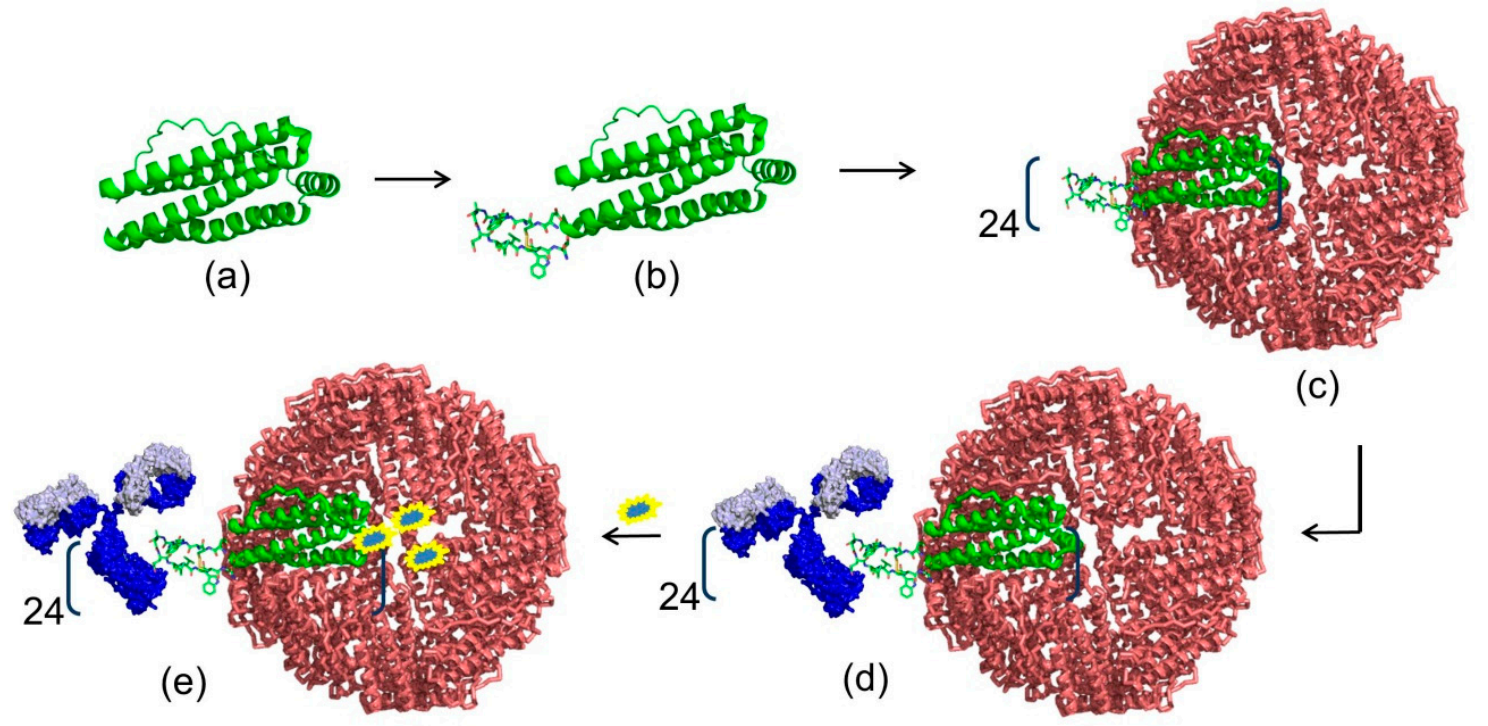

Figure 6. Illustration of the complexation of anti-Her2 antibody on a protein nanocage (ferritin) surface using the Fc-binding peptide Fc-III. (a) Ferritin monomer; (b) genetically engineered ferritin fusion monomer with Fc-III inserted in one of the loops; (c) self-assembled ferritin nanocage with 24 surface exposed Fc-III; (d) non-covalent binding of anti-Her2 antibody to the Fc-III functionalized protein nanocage; (e) covalent fluorescent labeling of the protein nanocage.

SKBR3 breast cancer cells that overexpress Her receptors were treated with the functionalized nanocage (Figure 7). As a negative control, MCF10A breast cells that do not express Her receptors were used. Using fluorescent microscopy, it was clearly demonstrated that the Ab functionalized ferritin nanocage specifically targets the Her receptors on the SKBR3 breast cancer cells (MCF10A cells were not targeted).

Recently our group developed an Ab transducer based on $\mathrm{Fc}$-III, conjugated to the cell penetrating peptide Tat (Figure 8) [73]. In addition to the Fc-III/Tat conjugate, the fusions construct Fc-III/eGFP/Tat was prepared that includes the green fluorescent protein (GFP). Upon mixing of the two constructs in the cell growth media they readily targeted the Fc-domain of IgGs. Consequently, the targeted Abs translocated into the cytosol of live cells. The delivery of fluorescent labeled (Cy3, red) human IgG with the aid of the Fc-III/eGFP/Tat construct could be detected using fluorescent microscopy. 


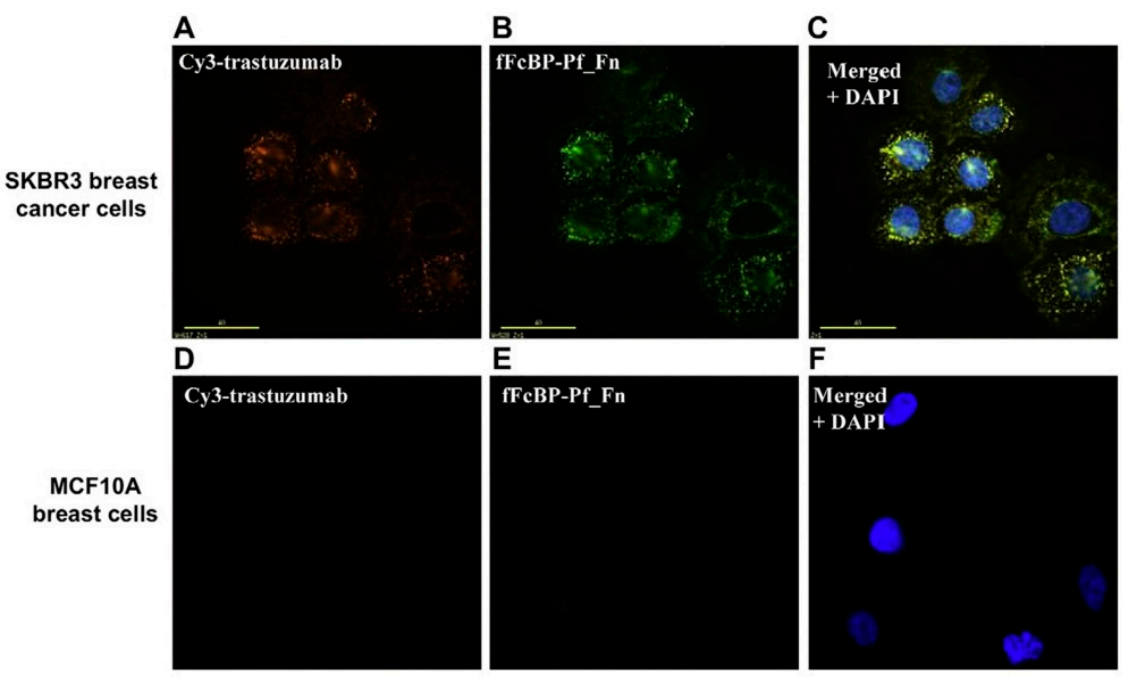

Figure 7. Fluorescent microscopic images of SKBR3 breast cancer cells (A-C) and MCF10A breast cells (D-F) treated with Cy3-trastuzumab/fFcBP-Pf_Fn complexes. Trastuzumab and FcBP-Pf_Fn were labeled with Cy3 (Cy3-trastuzumab) and fluorescein (fFcBP-Pf_Fn), respectively. Cy3-trastuzumab was simply mixed with fFcBP-Pf_Fn to form Cy3-trastuzumab/fFcBP-Pf_Fn complexes and subsequently incubated with SKBR3 breast cancer cells and MCF10A breast cells in the presence of excess amounts of rabbit serum. Cy3-trastuzumab and fFcBP-Pf_Fn are visualized as orange and green, respectively, by fluorescence microscopy. (For interpretation of the references to color in this figure legend, the reader is referred to the web version of this article.) Adapted from [71], with permission from ( 2012 Elsevier.

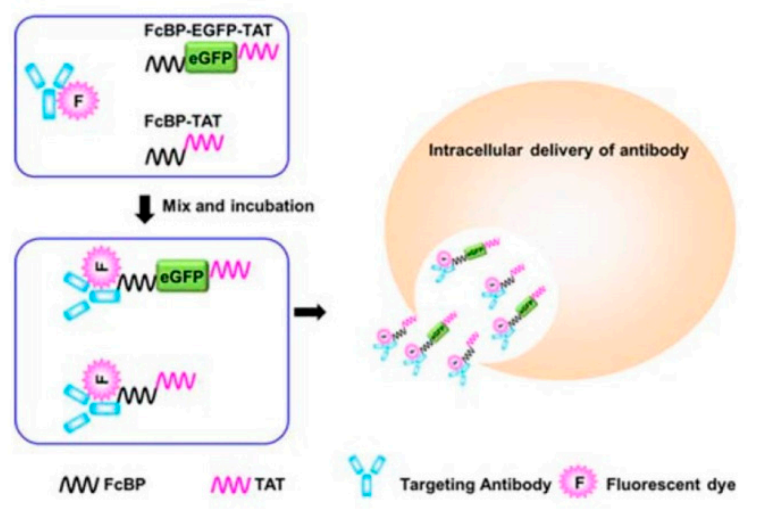

(a)

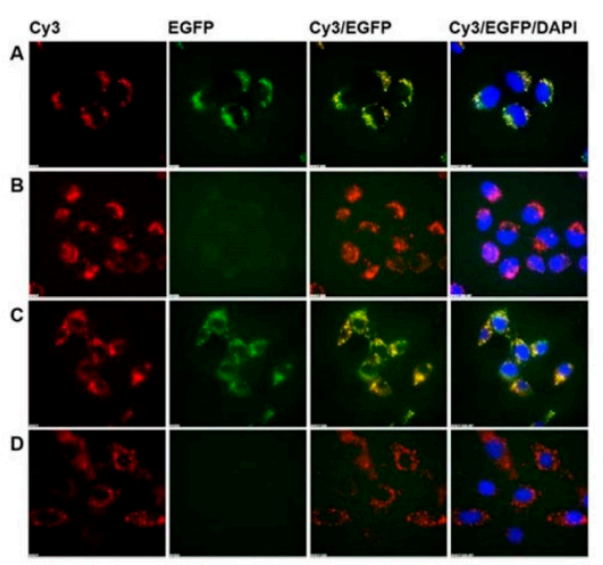

(b)

Figure 8. (a) Illustration of fluorescent labeled antibody delivery into live cells using the Fc-domain binding peptide (FcBP) Fc-III conjugated to the cell penetrating peptide Tat in addition to the green fluorescent protein; (b) Delivery of human IgG into live cells using the Fc-III/eGFP/Tat constructs. Cells were treated with Cy3 labelled human IgG (Cy3hIgG) in the presence of the Fc-III/eGFP/Tat or Fc-III/Tat. Cy3 (red): the fluorescence images of Cy3-hIgG (Ex/Em = 555/605 nm); EGFP: the fluorescence of eGFP the fluorescence (green) of eGFP $(\mathrm{Ex} / \mathrm{Em}=490 / 525 \mathrm{~nm})$; Nucleus (blue) was stained with DAPI $(\mathrm{Ex} / \mathrm{Em}=350 / 455 \mathrm{~nm})$; Cy3/eGFP: superimposition of Cy3-hIgG and FcBP-eGFP-Tat fluorescence images; Cy3/eGFP/DAPI: superimposition of Cy3-hIgG, FcBP-eGFP-Tat and DAPI fluorescence images. (A) HeLa cells treated with Cy3-hIgG and FcBP-eGFP-Tat; (B) HeLa cells treated with Cy3-hIgG and FcBP-Tat; (C) 3T3-L1 cells treated with Cy3-hIgG and FcBP-eGFP-Tat; (D) 3T3-L1 cells treated with Cy3-hIgG and FcBP-Tat. Adapted from [73], with permission from (C) 2015 Springer. 
Sockolosky and coworker reported a substantial increase of the half-life of recombinant proteins that are fused to the Fc-binding protein Fc-III (Figure 9) [74]. The fusion of Fc-III to the C-terminus of a model far-red bright fluorescent protein, Katushka (mKate), specifically bind to human IgG (affinity: $\mathrm{pH}=7.4-40 \mathrm{nM} ; \mathrm{pH}=6-20 \mathrm{nM}$ ). Interestingly, although Fc-III is known to interfere with FcRn binding (as discussed before, FcRn is involved in the endosomal salvation of IgG) the half-life of the Fc-III fusion protein showed a 75 fold increase (up to $8 \mathrm{~h}$ ) in human FcRn transgenic mouse when the fusion protein and human IgG1 are mixed in a 1:1 ratio with respect to unmodified mKate.

Muguruma and coworkers recently reported the development of a non-covalent antibody-drug conjugate (NC-ADC) based on the synthetic 33-mer Fc-binding peptide Z33 (Scheme 1) [75]. In their approach, the anticancer agent plinabulin was covalently linked to Z33 using Click chemistry. Next, high binding affinity of the cytotoxic conjugate to anti-Her2 Ab (Herceptin) and anti-CD71 Ab (6E1) was observed with a $K_{\mathrm{d}}=46.6 \pm 0.5 \mathrm{nM}$ and $4.5 \pm 0.56 \mu \mathrm{M}$, respectively. The prepared NC-ADC (with Herceptin) was evaluated against SKBR-3 cancer cells that overexpress Her-2 receptors versus MCF-7 cells that have low expression of Her-2 receptors (Figure 10). As expected, in cell based assays the NC-ADC shows a significant cytotoxicity in the presence of Herceptin towards SKBR-3 cells whereas the MCF-7 cells are not affected. In case of the NC-ADC with 6E1, similar results were obtained.

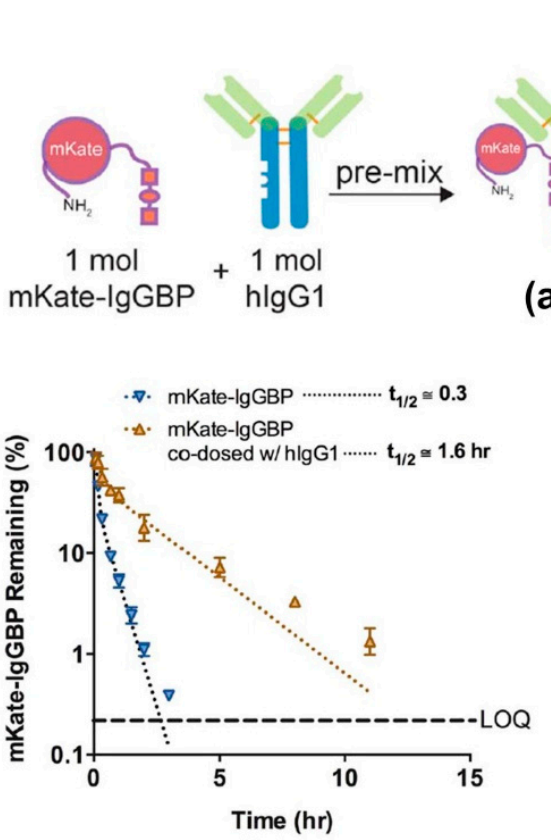

(b)
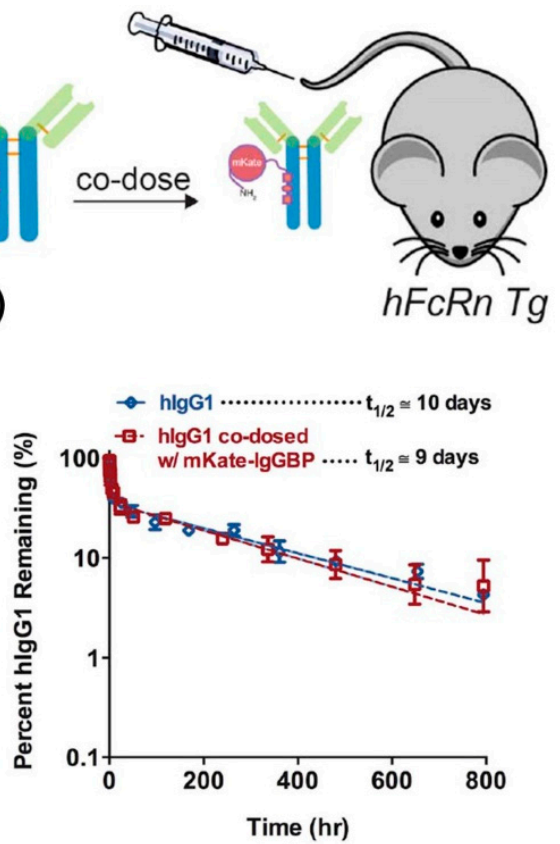

(c)

Figure 9. (a) Schematic of the co-administration scheme. In this experiment, human FcRn Tg mice were not pre-dosed with exogenous hIgG1. Instead mKate-IgGBP and hIgG1 were pre-mixed in a 1:1 molar ratio and co-injected via the tail vein; (b) clearance of mKate-IgGBP in hFcRn Tg mice dosed alone (blue triangles) or co-dosed at a 1:1 molar mixture with hIgG1 (yellow triangles). The mKate-IgGBP remaining $(\%)$ was calculated by normalizing the fluorescent emission at all time points to the maximum value observed in the first bleed 5 min after protein injection; (c) clearance of labeled human IgG1 in $\mathrm{hFcRn} \mathrm{Tg}$ mice dosed as a single agent via the tail vein (blue triangles) compared to the clearance of labeled hIgG1 co-administered as a 1:1 molar mixture with mKate-IgGBP was measured to determine if bound mKate-IgGBP alters the eliminate profile of hIgG1 (red squares). The hIgG1 remaining (\%) was calculated by normalizing the fluorescent emission at all time points to the maximum value observed in the first bleed $5 \mathrm{~min}$ after protein injection. Dashed lines in each panel represent the data fit to a 2-compartment PK model in Prism and the $\beta$-phase half-life shown in the figure was calculated as described in the Methods section. The data shown in each panel are the mean $(n=3$ bleeds per time point) and error bars indicate standard deviation. Adapted from [74]. 

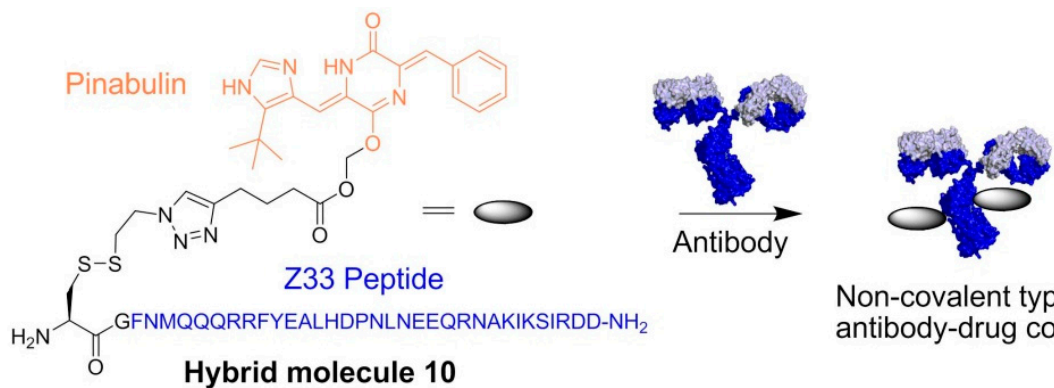

Non-covalent type antibody-drug conjugate

Scheme 1. Preparation of non-covalent antibody-drug conjugate using Pinabulin (cytotoxic agent) and Fc-binding peptide Z33.
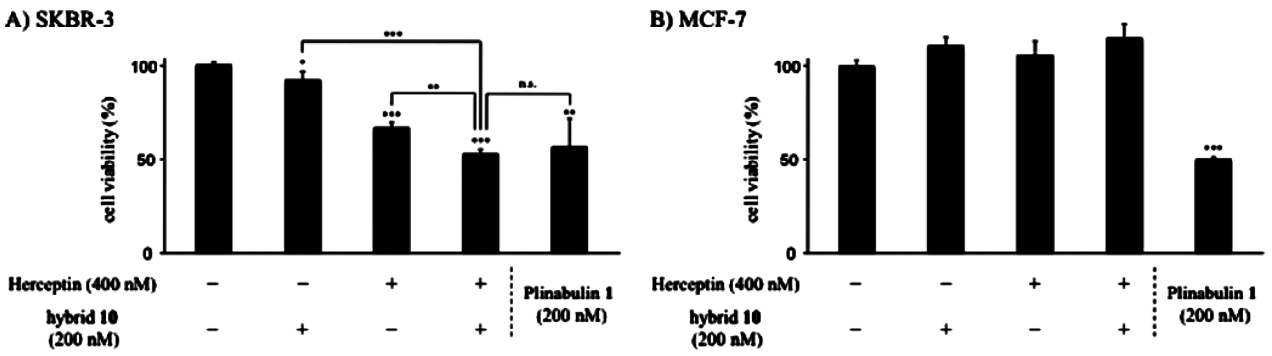

C) SKBR-3HR
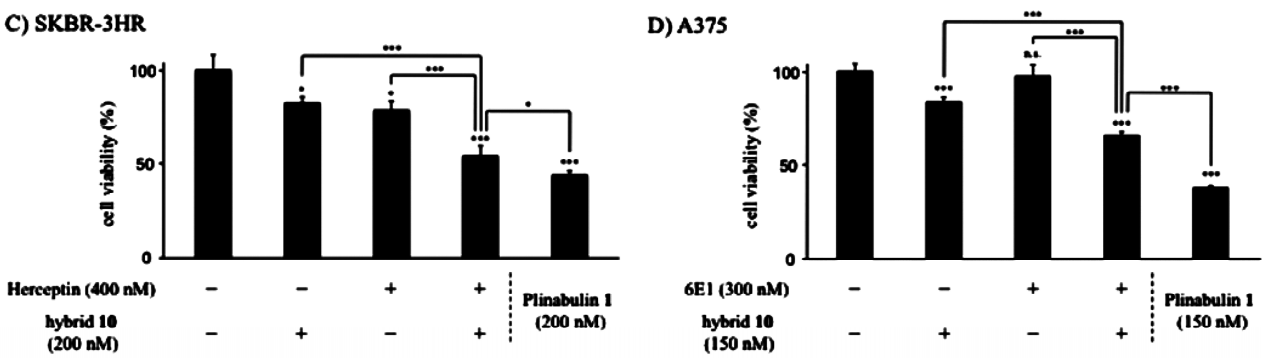

Figure 10. Cytotoxicity of NC-ADC, complex of hybrid 10 and Herceptin, against (A) SKBR-3 cells; (B) MCF-7 cells; and (C) SKBR-3HR cells; (D) cytotoxicity of noncovalent ADC, complex of hybrid 10 and 6 E1 against A375 cell. n.s.: not significant, ${ }^{*} p<0.05,{ }^{* *} p<0.01,{ }^{* * *} p<0.005$. Data $(n=3)$ are shown as means \pm SD. Adapted from [75], with permission from (C) 2016 American Chemical Society.

\section{Conclusions and Outlook}

Immunoglobulin binding proteins have played a pivotal role in advancing antibody purification technologies. To this end, three key bacterial proteins (A, G, and L) have been extensively used and modified (both genetic and chemical) to enhance their properties for use in affinity purification chromatography of antibodies. The importance of these bacterial proteins has stimulated the search for synthetic immunoglobulin binding proteins. Especially, synthetic ligands that target the Fc-binding domain of antibodies are highly desirable because Fc-binding ligands do not interfere with the antigen binding ability of immunoglobulins. Several peptide based Fc-binding high affinity ligands were discovered over the past 20 years and used mainly in affinity chromatographic purifications of antibodies. However, as antibody technologies are becoming increasingly more important, Fc-binding ligands are finding broader applications. For instance, Fc-binding ligands have been used to bind antibodies on the surface of protein nanocages in targeted drug delivery approaches in anticancer therapeutics. In addition, Fc-binding ligands have been applied in the capturing of antibodies on solid surfaces in the development of biosensors as well as in the development of antibody-drug conjugates. Interestingly, Fc-binding ligands have been shown to inhibit FcRn binding. Because FcRn plays a crucial role in the long circulation times of antibodies, Fc-binding ligands holds high potential in 
the treatment of autoimmune diseases. The inhibition of FcRn binding can drastically influence the antibody half-life.

Acknowledgments: This work was supported by the Bio-Synergy Research Project (NRF-2012M3A9C4048775) and the Pioneer Research Center Program (NRF-2012-0009543) of the Ministry of Science, ICT and Future Planning through the National Research Foundation.

Author Contributions: S.J.C. conceived and edited the manuscript. W.C. and T.A.D. wrote the review.

Conflicts of Interest: The authors declare no conflict of interest.

\section{References}

1. Steinitz, M. Three decades of human monoclonal antibodies: Past, present and future developments. Hum. Antibodies 2009, 18, 1-10. [PubMed]

2. Leavy, O. Therapeutic antibodies: Past, present and future. Nat. Rev. Immunol. 2010, 10, 297. [CrossRef] [PubMed]

3. Matera, M.G.; Page, C.; Rogliani, P.; Calzetta, L.; Cazzola, M. Therapeutic monoclonal antibodies for the treatment of chronic obstructive pulmonary disease. Drugs 2016, 76, 1257-1270. [CrossRef] [PubMed]

4. Mould, D.R.; Meibohm, B. Drug development of therapeutic monoclonal antibodies. BioDrugs 2016, 30, 275-293. [CrossRef] [PubMed]

5. Lambour, J.; Naranjo-Gomez, M.; Piechaczyk, M.; Pelegrin, M. Converting monoclonal antibody-based immunotherapies from passive to active: Bringing immune complexes into play. Emerg. Microbes Infect. 2016, 5, e92. [CrossRef] [PubMed]

6. Liu, J.K. The history of monoclonal antibody development-Progress, remaining challenges and future innovations. Ann. Med. Surg. (Lond.) 2014, 3, 113-116. [CrossRef] [PubMed]

7. Hamblett, K.J.; Le, T.; Rock, B.M.; Rock, D.A.; Siu, S.; Huard, J.N.; Conner, K.P.; Milburn, R.R.; O'Neill, J.W.; Tometsko, M.E.; et al. Altering antibody-drug conjugate binding to the neonatal Fc receptor impacts efficacy and tolerability. Mol. Pharm. 2016, 13, 2387-2396. [CrossRef] [PubMed]

8. Jendeberg, L.; Nilsson, P.; Larsson, A.; Denker, P.; Uhlen, M.; Nilsson, B.; Nygren, P.-A. Engineering of $\mathrm{F}_{\mathrm{C}_{1}}$ and $\mathrm{Fc}_{3}$ from human immunoglobulin $\mathrm{G}$ to analyse subclass specificity for staphylococcal protein $\mathrm{A}$. J. Immunol. Methods 1997, 201, 25-34. [CrossRef]

9. Deisenhofer, J. Crystallographic refinement and atomic models of a human Fc fragment and its complex with fragment B of protein A from staphylococcus aureus at 2.9- and 2.8-Å resolution. Biochemistry 1981, 20, 2361-2370. [CrossRef] [PubMed]

10. Arora, I. Chromatographic methods for the purification of monoclonal antibodies and their alternatives: A review. IJETAE 2013, 3, 475-481.

11. Gaughan, C.L. The present state of the art in expression, production and characterization of monoclonal antibodies. Mol. Divers. 2016, 20, 255-270. [CrossRef] [PubMed]

12. Ey, P.L.; Prowse, S.J.; Jenkin, C.R. Isolation of pure IgG1, IgG2a and IgG2b immunoglobulins from mouse serum using protein A-sepharose. Immunochemistry 1978, 15, 429-436. [CrossRef]

13. Huse, K.; Bohme, H.J.; Scholz, G.H. Purification of antibodies by affinity chromatography. J. Biochem. Biophys. Methods 2002, 51, 217-231. [CrossRef]

14. Billakanti, J.M.; Fee, C.J.; Naik, A.D.; Carbonell, R.G. Application of peptide chromatography for the isolation of antibodies from bovine skim milk, acid whey and colostrum. Food Bioprod. Process. 2014, 92, 199-207. [CrossRef]

15. Hober, S.; Nord, K.; Linhult, M. Protein A chromatography for antibody purification. J. Chromatogr. B Analyt. Technol. Biomed. Life Sci. 2007, 848, 40-47. [CrossRef] [PubMed]

16. Gronemeyer, P.; Ditz, R.; Strube, J. Trends in upstream and downstream process development for antibody manufacturing. Bioengineering 2014, 1, 188-212. [CrossRef]

17. Roque, A.C.; Silva, C.S.; Taipa, M.A. Affinity-based methodologies and ligands for antibody purification: Advances and perspectives. J. Chromatogr. A 2007, 1160, 44-55. [CrossRef] [PubMed]

18. Fassina, G.; Ruvo, M.; Palombo, G.; Verdoliva, A.; Marino, M. Novel ligands for the affinity-chromatographic purification of antibodies. J. Biochem. Biophys. Methods 2001, 49, 481-490. [CrossRef] 
19. Kabir, S. Immunoglobulin purification by affinity chromatography using protein A mimetic ligands prepared by combinatorial chemical synthesis. Immunol. Investig. 2002, 31, 263-278. [CrossRef]

20. Thapa, P.; Espiritu, M.J.; Cabalteja, C.; Bingham, J.P. The emergence of cyclic peptides: The potential of bioengineered peptide drugs. Med. Chem. 2014, 4, 451-468. [CrossRef]

21. Smith, G.P. Filamentous fusion phage: Novel expression vectors that display cloned antigens on the viron surface. Science 1985, 228, 1315-1317. [CrossRef] [PubMed]

22. Bazan, J.; Calkosinski, I.; Gamian, A. Phage display-A powerful technique for immunotherapy: 1. Introduction and potential of therapeutic applications. Hum. Vaccin Immunother. 2012, 8, 1817-1828. [CrossRef] [PubMed]

23. Rodrigo, G.; Gruvegard, M.; Van Alstine, J.M. Antibody fragments and their purification by protein L affinity chromatography. Antibodies 2015, 4, 259-277. [CrossRef]

24. Konrad, A.; Karlstrom, A.E.; Hober, S. Covalent immunoglobulin labeling through a photoactivable synthetic Z domain. Bioconjug. Chem. 2011, 22, 2395-2403. [CrossRef] [PubMed]

25. Kihlberg, B.M.; Sjoholm, A.G.; Bjorck, L.; Sjobring, U. Characterization of the binding properties of protein LG, an immunoglobulin-binding hybrid protein. Eur. J. Biochem. 1996, 240, 556-563. [CrossRef] [PubMed]

26. Nilsson, B.; Moks, T.; Jansson, B.; Abrahmsén, L.; Elmblad, A.; Holmgren, E.; Henrichson, C.; Jones, T.A.; Uhlén, M. A synthetic IgG-binding domain based on staphylococcal protein A. Protein Eng. Des. Sel. 1987, 1, 107-113. [CrossRef]

27. Ghitescu, L.; Galis, Z.; Bendayan, M. Protein AG-gold complex: An alternative probe in immunocytochemistry. J. Histochem. Cytochem. 1991, 39, 1057-1065. [CrossRef] [PubMed]

28. Akerstrom, B.; Bjorck, L. A physicochemical study of protein G, a moleculle with unique immunoglobulin G-binding properties. J. Biol. Chem. 1986, 261, 10240-10247. [PubMed]

29. Svensson, H.; Hoogenboom, H.R.; Sjöbring, U. Protein LA, a novel hybrid protein with unique single-chain Fv antibody- and Fab-binding properties. Eur. J. Biochem. 1998, 258, 890-896. [CrossRef] [PubMed]

30. Moks, T.; Abrahmsen, L.; Nilsson, B.; Hellman, B.; Sjöquist, J.; Uhlen, M. Staphylococcal protein A consist of five IgG-binding domains. Eur. J. Biochem. 1986, 156, 637-643. [CrossRef] [PubMed]

31. Graille, M.; Stura, E.A.; Corper, A.L.; Sutton, B.J.; Taussig, M.J.; Charbonnier, J.B.; Silverman, G.J. Crystal structure of a Staphylococcus aureus protein A domain complexed with the Fab fragment of a human IgM antibody: Structural basis for recognition of B-cell receptors and superantigen activity. Proc. Natl. Acad. Sci. USA 2000, 97, 5399-5404. [CrossRef] [PubMed]

32. Saha, K.; Bender, F.; Gizeli, E. Comparative study of IgG binding to proteins G and A: Nonequilibrium kinetic and binding constant determination with the acoustic waveguide device. Anal. Chem. 2003, 75, 835-842. [CrossRef] [PubMed]

33. Pabst, T.M.; Palmgren, R.; Forss, A.; Vasic, J.; Fonseca, M.; Thompson, C.; Wang, W.K.; Wang, X.; Hunter, A.K. Engineering of novel staphylococcal protein A ligands to enable milder elution $\mathrm{pH}$ and high dynamic binding capacity. J. Chromatogr. A 2014, 1362, 180-185. [CrossRef] [PubMed]

34. Tashira, M.; Tejero, R.; Zimmerman, D.E.; Celda, B.; Nilsson, B.; Montelione, G.T. High-resolution solution NMR structure of the Z domain of staphylococcal protein A. J. Mol. Biol. 1997, 272, 573-590. [CrossRef] [PubMed]

35. Braisted, A.; Wells, J.A. Minimizing a binding domain from protein. Proc. Natl. Acad. Sci. USA 1996, 93, 5688-5692. [CrossRef] [PubMed]

36. Mouratou, B.; Behar, G.; Pecorari, F. Artificial affinity proteins as ligands of immunoglobulins. Biomolecules 2015, 5, 60-75. [CrossRef] [PubMed]

37. Watanabe, H.; Matsumaru, H.; Ooishi, A.; Feng, Y.; Odahara, T.; Suto, K.; Honda, S. Optimizing pH response of affinity between protein $\mathrm{G}$ and IgG Fc: How electrostatic modulations affect protein-protein interactions. J. Biol. Chem. 2009, 284, 12373-12383. [CrossRef] [PubMed]

38. Tsukamoto, M.; Watanabe, H.; Ooishi, A.; Honda, H. Engineerd protein A ligands, derived from a histidine-scanning library, facilitate the affinity purification of IgG under mild acidic conditions. J. Biol. Eng. 2014, 8, 15-24. [CrossRef] [PubMed]

39. Gulich, S.; Uhlen, M.; Hober, S. Protein engineering of an IgG-binding domain allows milder elution conditions during affinity chromatography. J. Biotechnol. 2000, 76, 233-243. [CrossRef]

40. Strauch, E.M.; Fleishman, S.J.; Baker, D. Computational design of a pH-sensitive IgG binding protein. Proc. Natl. Acad. Sci. USA 2014, 111, 675-680. [CrossRef] [PubMed] 
41. Gera, N.; Hill, A.B.; White, D.P.; Carbonell, R.G.; Rao, B.M. Design of pH sensitive binding proteins from the hyperthermophilic Sso7d scaffold. PLoS ONE 2012, 7, e48928. [CrossRef] [PubMed]

42. DeLano, W.L.; Ultsch, M.H.; de Vos, A.M.; Wells, J.A. Convergent solutions to binding at a protein-protein interface. Science 2000, 287, 1279-1283. [CrossRef] [PubMed]

43. Makaraviciute, A.; Ramanaviciene, A. Site-directed antibody immobilization techniques for immunosensors. Biosens. Bioelectron. 2013, 50, 460-471. [CrossRef] [PubMed]

44. Jung, Y.; Lee, J.M.; Kim, J.; Yoon, J.; Cho, H.; Chung, B.H. Photoactivatable antibody binding protein: Site-selective and covalent coupling of antibody. Anal. Chem. 2009, 81, 936-942. [CrossRef] [PubMed]

45. Fassina, G.; Verdoliva, A.; Odierna, M.R.; Ruvo, M.; Cassini, G. Protein A mimetic peptide ligan for affinity purification of antibodi. J. Mol. Recognit 1996, 9, 564-569. [CrossRef]

46. Verdoliva, A.; Pannone, F.; Rossi, M.; Catello, S.; Manfredi, V. Affinity purification of polyclonal antibodies using a new all-D synthetic peptide ligand: Comparison with protein A and protein G. J. Immunol. Methods 2002, 271, 77-88. [CrossRef]

47. Dinon, F.; Salvalaglio, M.; Gallotta, A.; Beneduce, L.; Pengo, P.; Cavallotti, C.; Fassina, G. Structural refinement of protein A mimetic peptide. J. Mol. Recognit 2011, 24, 1087-1094. [CrossRef] [PubMed]

48. Krook, M.; Mosbach, K.; Ramstrom, O. Novel peptides binding to the Fc-portion of immunoglobulins obtained from a combinatorial phage display peptide library. J. Immunol. Methods 1998, 221, 151-157. [CrossRef]

49. Kang, H.J.; Choe, W.; Min, J.K.; Lee, Y.M.; Kim, B.M.; Chung, S.J. Cyclic peptide ligand with high binding capacity for affinity purification of immunoglobulin G. J. Chromatogr. A 2016, 1466, 105-112. [CrossRef] [PubMed]

50. Dias, R.L.; Fasan, R.; Moehle, K.; Renard, A.; Obrecht, D.; Robinson, J.A. Protein ligand design: From phage display to synthetic protein epitope mimetics in human antibody Fc-binding peptidomimetics. J. Am. Chem. Soc. 2006, 128, 2726-2732. [CrossRef] [PubMed]

51. Gong, Y.; Zhang, L.; Li, J.; Feng, S.; Deng, H. Development of the double cyclic peptide ligand for antibody purification and protein detection. Bioconjug. Chem. 2016, 27, 1569-1573. [CrossRef] [PubMed]

52. Ehrlich, G.K.; Bailon, P. Identification of model peptides as affinity ligands for the purification of humanized monoclonal antibodies by means of phage disaplay. J. Biochem. Biophys. Method 2001, 49, 443-454. [CrossRef]

53. Camperi, S.A.; Iannucci, N.B.; Albanesi, G.J.; Eberhardt, M.O.; Etcheverrigaray, M.; Messequer, A.; Albericio, F.; Cascone, O. Monoclonal antibody purification by affinity chromatography with ligands derived from the screening of peptide combinatory libraries. Biotechnol. Lett. 2003, 25, 1545-1548. [CrossRef] [PubMed]

54. Verdoliva, A.; Marasco, D.; De Capua, A.; Saporito, A.; Bellofiore, P.; Manfredi, V.; Fattorusso, R.; Pedone, C.; Ruvo, M. A new ligand for immunoglobulin $g$ subdomains by screening of a synthetic peptide library. ChemBioChem 2005, 6, 1242-1253. [CrossRef] [PubMed]

55. Yang, H.; Gurgel, P.V.; Carbonell, R.G. Hexamer peptide affinity resin that bind the Fc region of human immunoglobulin G. J. Peptide Res. 2006, 66, 110-137. [CrossRef]

56. Yang, H.; Gurgel, P.V.; Carbonell, R.G. Purification of human immunoglobulin G via Fc-specific small peptide ligand affinity chromatography. J. Chromatogr. A 2009, 1216, 910-918. [CrossRef] [PubMed]

57. Menegatti, S.; Bobay, B.G.; Ward, K.L.; Islam, T.; Kish, W.S.; Naik, A.D.; Carbonell, R.G. Design of protease-resistant peptide ligands for the purification of antibodies from human plasma. J. Chromatogr. A 2016, 1445, 93-104. [CrossRef] [PubMed]

58. Lund, L.N.; Gustavsson, P.E.; Michael, R.; Lindgren, J.; Norskov-Lauritsen, L.; Lund, M.; Houen, G.; Staby, A.; St Hilaire, P.M. Novel peptide ligand with high binding capacity for antibody purification. J. Chromatogr. A 2012, 1225, 158-167. [CrossRef] [PubMed]

59. Menegatti, S.; Ward, K.L.; Naik, A.D.; Kish, W.S.; Blackburn, R.K.; Carbonell, R.G. Reversible cyclic peptide libraries for the discovery of affinity ligands. Anal. Chem. 2013, 85, 9229-9237. [CrossRef] [PubMed]

60. Menegatti, S.; Hussain, A.; Naik, A.D.; Carbonell, R.G.; Rao, B.M. mRNA display selection and solid-phase synthesis of Fc-binding cyclic peptide affinity ligands. Biotechnol. Bioeng. 2013, 110, 857-870. [CrossRef] [PubMed]

61. Sugita, T.; Katayama, M.; Okochi, M.; Kato, R.; Ichihara, T.; Honda, H. Screening of peptide ligands that bind to the Fc region of IgG using peptide array and its application to affinity purification of antibody. Biochem. Eng. J. 2013, 79, 33-40. [CrossRef]

62. Zhao, W.-W.; Liu, F.-F.; Shi, Q.-H.; Dong, X.-Y.; Sun, Y. Biomimetic design of affinity peptide ligands for human IgG based on protein A-IgG complex. Biochem. Eng. J. 2014, 88, 1-11. [CrossRef] 
63. Zhao, W.W.; Shi, Q.H.; Sun, Y. FYWHCLDE-based affinity chromatography of IgG: Effect of ligand density and purifications of human IgG and monoclonal antibody. J. Chromatogr. A 2014, 1355, 107-114. [CrossRef] [PubMed]

64. Zhao, W.W.; Liu, F.F.; Shi, Q.H.; Sun, Y. Octapeptide-based affinity chromatography of human immunoglobulin G: Comparisons of three different ligands. J. Chromatogr. A 2014, 1359, 100-111. [CrossRef] [PubMed]

65. Zhao, W.W.; Shi, Q.H.; Sun, Y. Dual-ligand affinity systems with octapeptide ligands for affinity chromatography of hIgG and monoclonal antibody. J. Chromatogr. A 2014, 1369, 64-72. [CrossRef] [PubMed]

66. Tsai, C.W.; Jheng, S.L.; Chen, W.Y.; Ruaan, R.C. Strategy of Fc-recognizable Peptide ligand design for oriented immobilization of antibody. Anal. Chem. 2014, 86, 2931-2938. [CrossRef] [PubMed]

67. Yoo, R.-J.; Choi, S.-J. Identification of a peptide ligand for antibody immobilization on biosensor surfaces. BioChip J. 2015, 10, 88-94. [CrossRef]

68. Nair, M.; Vijayan, M.; Venkatachalapath, Y.V.; Balaram, P. X-ray Crystal Structure of Pivaloyl-[D]-Pro-L-ProL-Ala- $N$-methylamide; Observation of a Consecutive $\beta$-Turn Conformation. J. Chem. Soc. Chem. Commun. 1979, 1183-1184. [CrossRef]

69. Yang, H.; Gurgel, P.V.; Williams, D.K., Jr.; Bobay, B.G.; Cavanagh, J.; Muddiman, D.C.; Carbonell, R.G. Binding site on human immunoglobulin G for the affinity ligand HWRGWV. J. Mol. Recognit 2010, 23, 271-282. [CrossRef] [PubMed]

70. Jung, Y.; Kang, H.J.; Lee, J.M.; Jung, S.O.; Yun, W.S.; Chung, S.J.; Chung, B.H. Controlled antibody immobilization onto immunoanalytical platforms by synthetic peptide. Anal. Biochem. 2008, 374, 99-105. [CrossRef] [PubMed]

71. Kang, H.J.; Kang, Y.J.; Lee, Y.M.; Shin, H.H.; Chung, S.J.; Kang, S. Developing an antibody-binding protein cage as a molecular recognition drug modular nanoplatform. Biomaterials 2012, 33, 5423-5430. [CrossRef] [PubMed]

72. Ghisaidoobe, A.B.T.; Chung, S.J. Functionalized protein nanocages as a platform of targeted therapy and immunodetection. Nanomedicine 2015, 10, 3579-3595. [CrossRef] [PubMed]

73. Kang, H.J.; Choe, W.; Kim, B.M.; Chung, S.J. IgG Fc-binding peptide (FcBP)-tat conjugate as a smart antibody carrier into live cells. Macromol. Res. 2015, 23, 876-881. [CrossRef]

74. Sockolosky, J.; Kivimae, S.; Szoka, F. Fusion of a short protein that binds to immunoglobilin G to a recombinat protein substantially increases its plasma half-life in mice. PLoS ONE 2014, 9, e102566. [CrossRef] [PubMed]

75. Muguruma, K.; Yakushiji, F.; Kawamata, R.; Akiyama, D.; Arima, R.; Shirasaka, T.; Kikkawa, Y.; Taguchi, A.; Takayama, K.; Fukuhara, T.; et al. Novel hybrid compound of a plinabulin prodrug with an IgG binding peptide for generating a tumor selective noncovalent-type antibody-drug conjugate. Bioconjug. Chem. 2016, 27, 1606-1613. [CrossRef] [PubMed]

(c) 2016 by the authors; licensee MDPI, Basel, Switzerland. This article is an open access article distributed under the terms and conditions of the Creative Commons Attribution (CC-BY) license (http://creativecommons.org/licenses/by/4.0/). 